\title{
CONTROL SYSTEM OF SPONTANEOUS COMBUSTION IN COAL GANGUE DUMPS - A CASE STUDY AT YUQUAN COAL MINE IN CHINA
}

\author{
Gang Wang, Qiqi Liu, Guoqiang Yan, Lulu Sun, Hongyuan Qu, Qingfang Han
}

Preliminary communication Spontaneous combustion in coal gangue dumps leads to pollution in the environment and damages ecosystem and human health. Mine operators usually fail to take effective measures against spontaneous combustion because of the inaccurate detection of the location of spontaneous combustion bursts. To address this issue, a control system of spontaneous combustion in coal gangue dumps was designed and constructed in this study. The control system is composed of a detection system of spontaneous combustion areas, a mobile prevention and extinguishing system of spontaneous combustion using liquid carbon dioxide (LCD), and an effect-checking system of spontaneous combustion in coal gangue dump. First, the detection system was used to detect the spontaneous combustion areas in the coal gangue dumps. LCD was then injected into the combustion areas with its pressure injection equipment to lower the temperature in the coal gangue dumps below the ignition point of coal gangue and to force oxygen out of the dumps. Finally, the effect-testing system was used to test the effects of the two systems. The spontaneous combustion in coal gangue dumps was controlled through a case study at Yuquan coal mine. Results show that the concentrations of index gases $\mathrm{CO}$ and $\mathrm{H}_{2} \mathrm{~S}$ in the coal gangue dumps of Yuquan coal mine are below 24 and $6,6 \mathrm{ppm}$, and the internal temperature is below $70{ }^{\circ} \mathrm{C}$, The cost per square meter of the control system of spontaneous combustion is approximately $\$ 8$. Therefore, the proposed control system can economically and effectively control spontaneous combustion in coal gangue dumps, thereby preventing pollution in the environment.

Keywords: coal gangue dump; control system; effect-checking system; liquid carbon dioxide; spontaneous combustion

Sustav kontrole spontanog zapaljenja na odlagalištima jalovine uglja - studija slučaja rudnika ugljena Yuquan u Kini

Prethodno priopćenje

Spontano zapaljenje na odlagalištima jalovine uglja dovodi do zagađenja okoliša i oštećenja ekosustava i ljudskog zdravlja. Voditelji ugljenokopa obično ne poduzimaju učinkovite mjere sprečavanja spontanog zapaljenja zbog nepravovremenog otkrivanja mjesta izbijanja spontanog zapaljenja. Zbog toga je u ovom radu dizajniran i konstruiran sustav kontrole spontanog zapaljenja na odlagalištima jalovine. Taj se sustav sastoji od sustava za otkrivanje područja spontanog zapaljenja, pokretnog sustava za prevenciju i gašenje spontanog zapaljenja primjenom tekućeg ugljičnog dioksida (LCD - Liquid Carbon Dioxide) i sustava za provjeru učinka spontanog zapaljenja u odlagalištu jalovine. Prvo je sustavom otkrivanja otkriveno područje spontanog zapaljenja na odlagalištu, Zatim je u zapaljeno područje uštrcan LCD pomoću opreme za uštrcavanje kako bi se temperatura u odlagalištu smanjila ispod točke zapaljenja ugljene jalovine i kako bi se kisik izbacio iz odlagališta. Konačno, sustavom za provjeru učinkovitosti ispitali su se učinci dvaju sustava. Spontano zapaljenje na odlagalištima jalovine provjereno je na analizi slučaja u Yuquan rudniku. Rezultati pokazuju da su koncentracije plinova CO $\mathrm{i}$ $\mathrm{H}_{2} \mathrm{~S}$ na odlagalištu jalovine ugljenokopa Yuquan ispod 24 i $6,6 \mathrm{ppm}$, a unutarnja temperature je ispod $70{ }^{\circ} \mathrm{C}$. Cijena po kvadratnom metru sustava kontrole spontanog zapaljenja iznosi približno $\$ 8$. Prema tome, predloženim se kontrolnim sustavom može ekonomično i učinkovito nadgledati spontano zapaljenje na odlagalištima jalovine uglja, stoga i spriječiti zagađenje okoliša.

Ključne riječi: odlagalište jalovine uglja; spontano zapaljenje; sustav kontrole; sustav za provjeru učinaka; tekući ugljični dioksid

\section{Introduction}

The increase in scale and output of coal production has also increased coal gangue dumps as inevitable solid wastes generated from coal mining, washing, and processing. Incomplete statistics collected up to 2010 indicate that China accumulated more than 4,5 billion tons of coal gangue, occupying more than $15000 \mathrm{~km}^{2}$ of land [1]. These coal gangue dumps occupy large tracts of lands and emit large amounts of poisonous and inflammable gases, such as sulfur dioxide, hydrogen sulfide, and nitrogen oxides [2]. When exposed to ambient conditions, these inflammable gases and residual coals become susceptible to spontaneous combustion. Spontaneous combustion in coal gangue dumps results mainly from the oxidation of organic matters or inorganic coal-bearing phases, such as pyrite. The exact mechanisms of spontaneous combustion in coal gangue dumps are not fully understood because their onset, development, and end process are influenced by many complex internal and external factors, such as oxidation, ambient temperature, thermal conductivity, grain size, coalification rank, volatile matters, and tectonic influence $[3 \div 14]$. These influencing factors result in difficulty in forecasting for the effective control of spontaneous combustion in coal gangue dumps.

\section{State of the art}

Fundamental studies have been conducted to control spontaneous combustion in coal gangue dumps. Kim and Chaiken [15] proposed a burnout control method for accelerating the in situ burning in coal gangue dumps and simultaneously setting the heat under controlled conditions. The specific steps of the method are as follows: 1) horizontal channels for controlling air supply were drilled within the coal gangue dump with compacted soil; 2) the coal gangue dump was artificially lighted, and an introduced draft fan was used to vacuum the combustion manifold pipe, with a perforated end section inserted into the combustion zone of the coal gangue dump to withdraw combustion products; 3 ) the heat of combustion products was utilized, and the refined combustion products were emitted through chimneys. Rynk [16] adopted the automatic sprinkler system and fire extinguisher to effectively control surface fires in coal gangue dumps, and employed the monitoring system and handling system to fight internal fires in coal gangue dumps. In brief, if the readings of thermometers or temperature sensors were in the range of $76 \div 80^{\circ} \mathrm{C}$, then signs of smoking and charring should be monitored. When smoking or charring was detected, the aeration system should be removed from the coal gangue dumps; 
when no smoking or charring occurred, the aeration system should be activated to cool the coal gangue dumps. Moreover, if the readings of thermometers or temperature sensors exceeded $90{ }^{\circ} \mathrm{C}$, then the aeration system should be shut down and removed from the coal gangue dumps until the burning sections were isolated and quenched. Dalverny and Chaiken [17] monitored the pressure, temperature, and concentration of gas at the bottom of boreholes that are drilled into coal gangue dumps. They also used exhaust fans attached to these boreholes to locate heated areas. They injected water and fume extinguishant into the boreholes to quench the heated areas. However, their method fails because of insufficient water that expands over the entire heated zones from injection points. Jones et al. [18] used grouting barriers to isolate the heated zones and firefighting foams for the purpose of extinguishing fires in coal gangue dumps. The containment barrier effectively reduces the permeating heat and stops a slew of pores in coal gangue dumps. The firefighting foams of medium density and medium expansion combined with the polyurethane grout containment barrier are efficient and cost-effective means to extinguish spontaneous combustion in coal gangue dumps. Kim and Kociban [19] developed a safe and effective method called cryogenic heat transfer to extinguish spontaneous combustion in coal gangue dumps. They used liquid nitrogen and solid carbon dioxide produced with accessible equipment in their method. Liquid nitrogen and solid carbon dioxide can absorb the heat of spontaneous combustion and replace air and gaseous products generated by spontaneous combustion. However, inaccurate detection of spontaneous combustion zones and implementation of non-specific methods for control may lead to the failure of mine operators in taking effective measures for controlling spontaneous combustion zones in coal gangue dumps.

To effectively and specifically control spontaneous combustion in coal gangue dumps, a control system of spontaneous combustion in coal gangue dumps was designed and constructed in the present study on the basis of the studies on the process of spontaneous combustion. With this system, spontaneous combustion zones can be accurately detected, spontaneous combustion can be effectively prevented and extinguished using liquid carbon dioxide (LCD), and the control effect can be objectively tested. This system was applied in Yuquan coal mine to effectively control the spontaneous combustion in its coal gangue dumps. The cost per square meter of the control system of spontaneous combustion is approximately $\$ 8$. Therefore, the proposed control system is economical. Considering the budget and development plans of Yuquan coal mine, the method of hierarchically rolling and covering with loess was adopted to prevent the spontaneous combustion in new coal gangues.

The rest of the paper is organized as follows. Section 3 designs and constructs the control system of spontaneous combustion in coal gangue dumps. Section 4 analyzes the site conditions of Yuquan coal mine and discusses the application of the proposed control system in the mine. Section 5 summarizes the conclusions.

\section{Methodology \\ 3.1 Mechanism of the control system of spontaneous combustion}

Spontaneous combustion in coal gangue dumps proceeds through the following four steps. 1) Combustibles that adsorb oxygen physically release adsorption heat, thereby heating up the dump. 2) When temperature rises to around $50{ }^{\circ} \mathrm{C}$, hydrocarbons and orperoxy complexes are oxygenated by chemical adsorption of oxygen on combustibles. 3) When temperature rises to the self-heating threshold of combustibles (around $70{ }^{\circ} \mathrm{C}$ ), oxygenated hydrocarbons and orperoxy-complexes are decomposed. Consequently, scarce gaseous products and stable oxycomplexes are released and unaltered coal matters are oxidized. 4) When temperature rises to the threshold of spontaneous combustion (around $150{ }^{\circ} \mathrm{C}$, depending on the different coalification ranks of coals), spontaneous combustion occurs. As a result, a large amount of gases are released, such as carbon dioxide, carbon monoxide, methane, hydrogen, ethane, ethylene, and other higher hydrocarbons. Therefore, cooling down the dumps and isolating them from air are the key measures to control spontaneous combustion in coal gangue dumps in addition to accurately detecting the areas of spontaneous combustion. Several specific methods have been adopted to control spontaneous combustion in coal gangue dumps. Among these methods, LCD injection is the most effective method for fire extinguishing because of its capability to refrigerate and suffocate coal gangue dumps. First, LCD emitted from its storage system with high pressure and low temperature changes rapidly from its liquid phase to its gas phase owing to a decrease in pressure and a 640-fold expansion in volume. Then, the vaporized and cryogenic LCD widely covers the coal gangue dumps fires and rapidly refrigerates and cools down the combustion zones. The vaporized carbon dioxide gas can also rapidly sink to the bottom of combustion areas and squeeze oxygen out owing to its higher density than air. Finally, gas carbon dioxide absorbs heat with its high adsorption power. This phenomenon halts the chain reactions of combustion and forces oxidation reaction to stop or end owing to its insufficient thermal polymerization conditions in cooled coal gangue dumps.

The proposed control system of spontaneous combustion in coal gangue dumps was designed and constructed on the basis of the studies on the process of spontaneous combustion. This control system consists of a detection system of spontaneous combustion areas, a mobile prevention and extinguishing system of spontaneous combustion using LCD, and an effectchecking system of spontaneous combustion in coal gangue dump. First, the detection equipment of the system is used to detect the spontaneous combustion areas in the coal gangue dumps. LCD is then injected into the combustion areas with its pressure injection equipment to lower the temperature of the gangue dumps to below the ignition point of coal gangue and to force oxygen out of the dumps. Finally, the effect-testing system composed of a multi-parameter gas detector and an armored platinum resistance temperature sensor is used to test the effects of 
the detection system and the prevention and extinguishing system.

\subsection{Detection system of spontaneous combustion areas 3.2.1 Main components}

The main components of the detection system of spontaneous combustion areas are $\mathrm{CWH760}$ portable infrared radiation thermometer, CD4 multi-parameter gas detector, truck driller, armored platinum resistance temperature sensor, and PC installed with the Surfer software.

\subsubsection{Working principle}

Monitoring the temperature and the concentrations of index gases and checking for the signs of smoking or charring are keys to detect spontaneous combustion in coal gangue dumps. First, the portable infrared radiation thermometers and the multi-parameter gas detectors are used to detect the temperature and the concentration of index gases on the surface of coal gangue dumps, respectively. $\mathrm{CO}$ and $\mathrm{H}_{2} \mathrm{~S}$ are selected as the index gases of spontaneous combustion because of the process and characteristics of spontaneous combustion in coal gangue dumps. The abnormal surface areas of coal gangue dumps are then confirmed through the isotherm of land surface obtained using the Surfer software to process the temperature data detected with the portable infrared radiation thermometers and the gas concentration data measured with the multi-parameter gas detectors. Finally, the boreholes deep into the normal areas of the gangue dumps are drilled with truck drillers for testing internal temperature and gas concentration of self-ignition. The internal temperatures and gas concentrations of $\mathrm{CO}$ and $\mathrm{H}_{2} \mathrm{~S}$ in the boreholes for detection are detected with the armored platinum resistance temperature sensors and multi-parameter gas detectors, respectively. The spontaneous combustion areas of coal gangue dumps are confirmed by the abnormal surface areas and the internal spontaneous combustion areas.

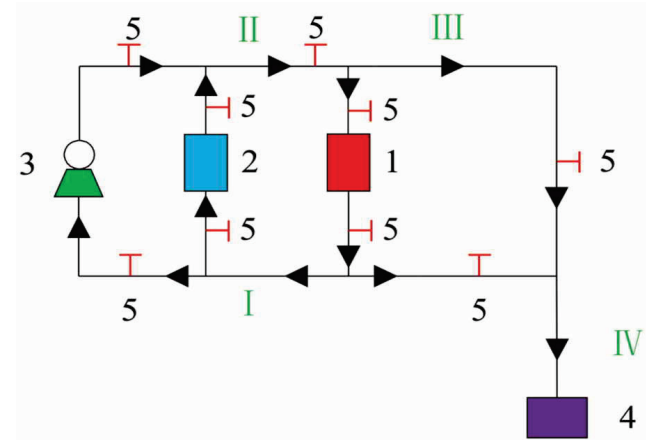

Figure 1 Schematic of the mobile prevention and extinguishing system of spontaneous combustion using LCD (1 - liquid storage tank; 2 - gasliquid converter of self-heating type; 3 - booster pump; 4 - injection equipment; 5 - control valves; I - liquid phase pipelines; II - liquid-gas mixed phase pipelines; III - gas phase pipelines; IV - high-vacuum insulation pipes). The direction of arrows represents the flow direction of liquid or gas carbon dioxide.

\subsection{Mobile prevention and extinguishing system of spontaneous combustion using LCD \\ 3.3.1 Main components}

The main components and schematic of the prevention and extinguishing system are shown in Fig. 1.

\subsubsection{Working principles}

The prevention and extinguishing system consists of an LCD injection system and a pressurization control system. The former is composed of a liquid storage tank, liquid phase pipelines, high-vacuum insulation pipes, injection equipment, and control valves. The latter comprises a booster pump, a gas-liquid converter of selfheating type, liquid phase pipelines, gas phase pipelines, liquid-gas mixed phase pipelines, and control valves. The LCD injection system is used for storing, conveying, and injecting LCD to prevent and extinguish spontaneous combustion in coal gangue dumps. The pressurization control system is designed to prevent decreases in the pressure of the liquid storage tank as LCD height constantly falls. Thus, the complete release of LCD in the liquid storage tank is ensured. The solidification of LCD is also prevented in the liquid storage tank, booster pump, gas-liquid converter of self-heating type, liquid phase pipelines, and high-vacuum insulation pipes.

\subsection{Effect-checking system of spontaneous combustion in coal gangue dump \\ 3.4.1 Main components}

The main components of the effect-testing system of spontaneous combustion in coal gangue dump are the CD4 multi-parameter gas detector and the armored platinum resistance temperature sensor.

\subsubsection{Working principles}

The effect-testing system of the control system of spontaneous combustion in coal gangue dump was designed and constructed according to the related requirements of "Coal Mine Safety Regulations" in China. The leading indicators of the effect-testing system are the concentration of index gases $\left(\mathrm{CO}\right.$ and $\left.\mathrm{H}_{2} \mathrm{~S}\right)$ and the internal temperature in coal gangue dumps. The specific working principles are based on the result of the detection system of spontaneous combustion areas. The effects of implementation of spontaneous combustion control are tested at $2,4,6,8,10$, and 12 months of post implementation.

\section{Result analysis and discussion 4.1 Site conditions}

Yuquan coal mine is located at the south of Yuxian Town in Shanxi Province of China. This coal mine belongs to Datun Coal and Electricity Group. The amount of approved mining seams is $8 \div 15$, and the amounts for elevation and scale of production are 959,87 $\div 789,87 \mathrm{~m}$ and 1,2 Mt/a. The coal gangue dumps in Yuquan coal mine currently have a total area of $22300 \mathrm{~m}^{2}$, and have caused significant damage to ecosystem and human health. Three coal gangue dumps exist in Yuquan coal mine. Among them, $1^{\#}$ and $2^{\#}$ are further divided into $1_{\text {under }}^{\#}$ r, $1_{\text {upper, }}^{\#} 2^{\#}{ }_{\text {upper }}$, and $2^{\#}{ }_{\text {under }}$ coal gangue dumps according to their topographies. Fig. 2 shows their 
location and surface shape. These dumps underwent spontaneous combustion. Fig. 3 shows the conditions of $1^{\#}$ coal gangue dump, in which a stone wall was built to prevent the fall of its south side close to the highway. The violent fire caused by spontaneous combustion blazed toward the stone wall and seriously threatened the safety of the highway. The cement mortar was sprayed toward the stone wall to block the fire passage and control the development of spontaneous combustion. However, the spontaneous combustion was not fully controlled. Fig. 4 shows the conditions of $2^{\#}$ dump. Dense smoke and strong pungent odor on the edge of the coal gangue layer and loess layer were observed. Many cracks on the surface allow oxygen to pass through the dump and accelerate spontaneous combustion. The conditions of $3^{\#}$ dump were approximately the same as those of the $2^{\#}$ dump and were thus not shown in the paper.

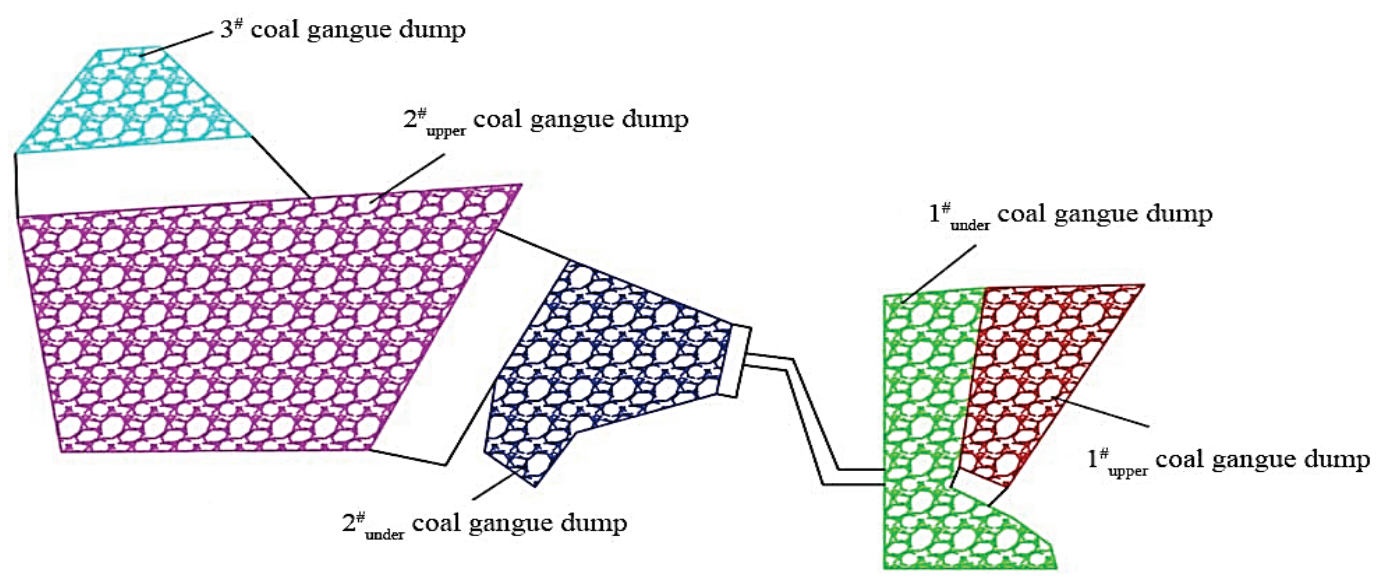

Figure 2 Location and surface shape of coal gangue dumps

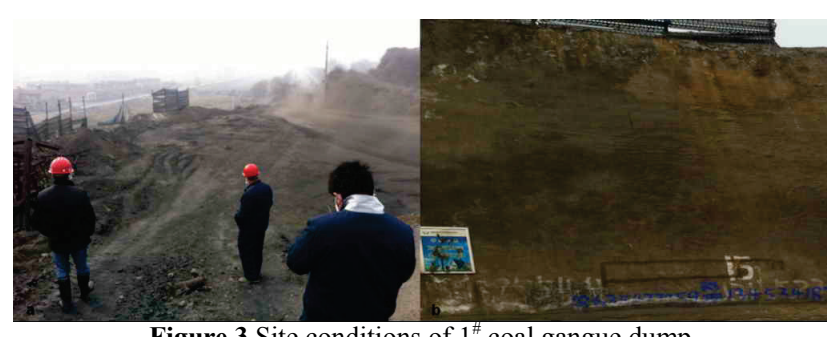

Figure 3 Site conditions of $1^{\#}$ coal gangue dump

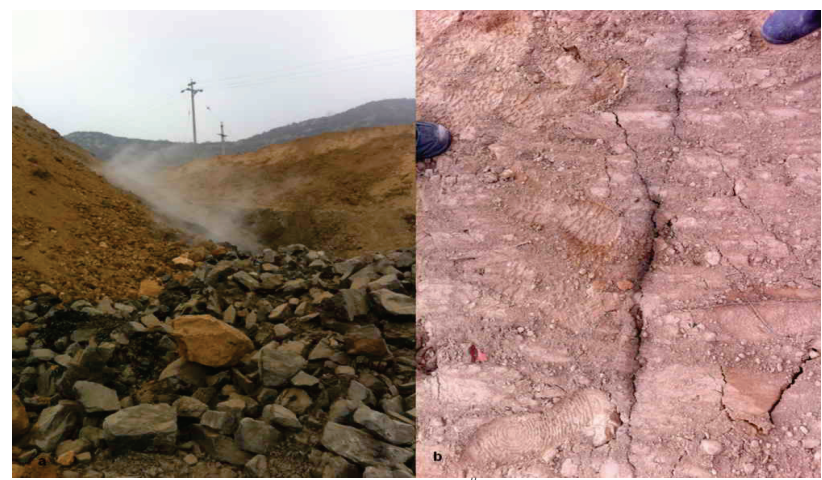

Figure 4 Site conditions of $2^{\#}$ coal gangue dump

\subsection{Application of the control system of spontaneous combustion}

\subsubsection{Detection of abnormal surface areas}

This section describes a case study on the abnormal surface areas of $2^{\#}$ under coal gangue dump. The portable infrared radiation thermometers and the multi-parameter gas detectors are used to detect the temperatures and gas concentrations of $\mathrm{CO}$ and $\mathrm{H}_{2} \mathrm{~S}$ on the surface of $2^{\#}$ under coal gangue dump, respectively. Fig. 5 shows the isotherm on the surface of $2^{\#}$ under coal gangue dump. This isothermal figure is drawn using the Surfer software on the basis of the tested data. Fig. 6 shows the isothermal figure related to the gas concentration on the two abnormal surface areas of the dump: A and B abnormal surface areas. The rectangle areas of $35 \mathrm{~m}$ long and $5 \mathrm{~m}$ wide and of $55 \mathrm{~m}$ long and $5 \mathrm{~m}$ wide are selected from $\mathrm{A}$ and B abnormal surface areas for mesh generation, respectively. The distributions of the detailed points in the rectangles are shown in Figs. 7 and 8. The distance between the detailed points in the same direction is $5 \mathrm{~m}$. The measured temperatures and gas concentrations of $\mathrm{CO}$ and $\mathrm{H}_{2} \mathrm{~S}$ of the detailed points are shown in Tab. 1 .

Table 1 Detected results of temperatures and concentrations of CO and

\begin{tabular}{|c|c|c|c|c|c|c|c|}
\hline . & 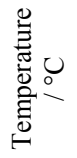 & $\frac{\Xi}{0}$ & 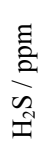 & 泀 & 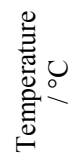 & $\frac{\Xi}{0}$ & 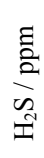 \\
\hline 1 & 41 & 96 & 28 & 21 & 33 & 16 & 10 \\
\hline 2 & 46 & 190 & 35 & 22 & 36 & 22 & 11 \\
\hline 3 & 43 & 87 & 25 & 23 & 29 & 135 & 58 \\
\hline 4 & 47 & 168 & 52 & 24 & 36 & 26 & 10 \\
\hline 5 & 42 & 26 & 12 & 25 & 33 & 56 & 23 \\
\hline 6 & 43 & 59 & 31 & 26 & 37 & 26 & 12 \\
\hline 7 & 46 & 167 & 54 & 27 & 35 & 26 & 11 \\
\hline 8 & 45 & 35 & 16 & 28 & 34 & 30 & 18 \\
\hline 9 & 43 & 38 & 16 & 29 & 29 & 21 & 11 \\
\hline 10 & 47 & 86 & 35 & 30 & 33 & 56 & 15 \\
\hline 11 & 45 & 36 & 12 & 31 & 36 & 38 & 12 \\
\hline 12 & 43 & 151 & 78 & 32 & 29 & 28 & 16 \\
\hline 13 & 42 & 56 & 21 & 33 & 33 & 176 & 63 \\
\hline 14 & 46 & 75 & 20 & 34 & 36 & 25 & 12 \\
\hline 15 & 41 & 18 & 11 & 35 & 35 & 18 & 9 \\
\hline 16 & 44 & 29 & 16 & 36 & 29 & 38 & 16 \\
\hline 17 & 32 & 18 & 12 & 37 & 30 & 132 & 25 \\
\hline 18 & 35 & 19 & 10 & 38 & 35 & 16 & 9 \\
\hline 19 & 28 & 31 & 15 & 39 & 32 & 21 & 10 \\
\hline 20 & 30 & 125 & 37 & 40 & 29 & 26 & 9 \\
\hline
\end{tabular}




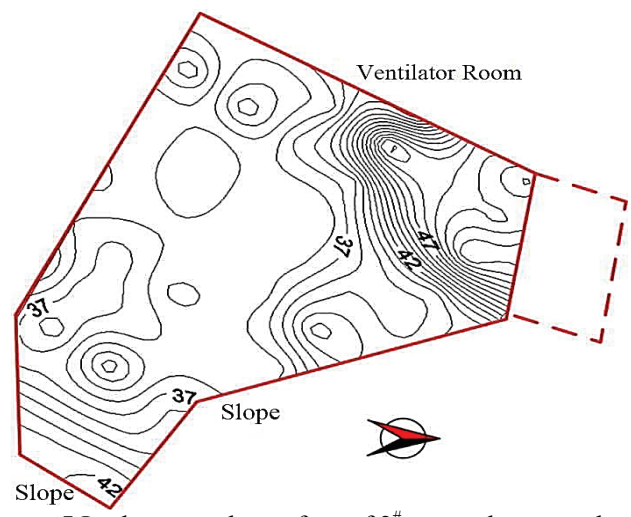

Figure 5 Isotherm on the surface of $2^{\#}$ under coal gangue dump

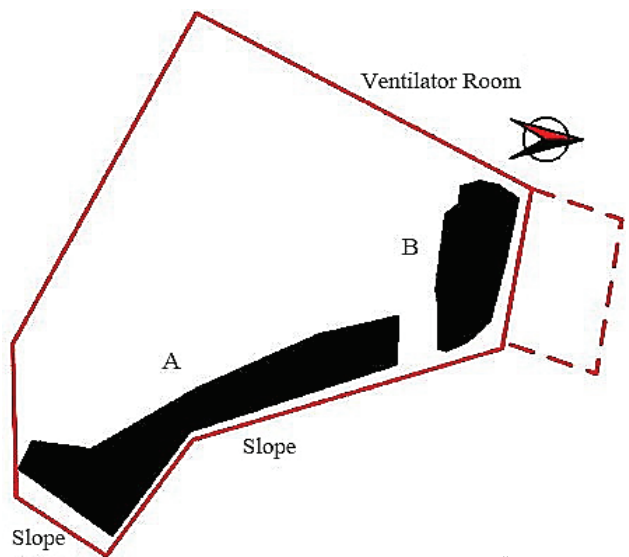

Figure 6 Abnormal surface areas (dark areas) of $2^{\#}$ under coal gangue dump

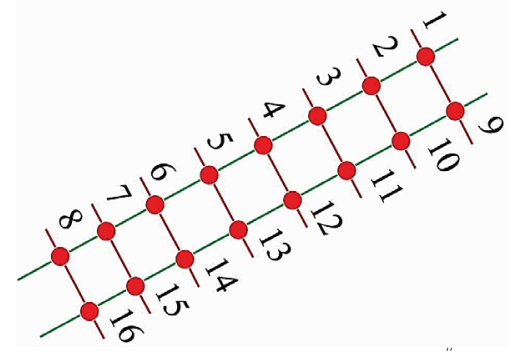

Figure 7 Layout of detailed points on A area of $2^{\#}$ under coal gangue

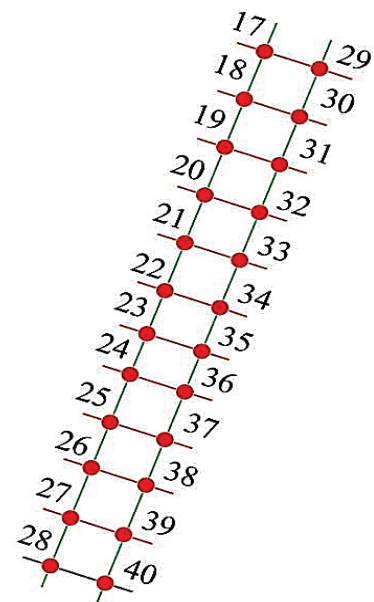

Figure 8 Layout of detailed points on B area of $2^{\#}$ under coal gangue

\subsubsection{Detection of internal spontaneous combustion areas}

The detection of temperatures and gas concentrations of $\mathrm{CO}$ and $\mathrm{H}_{2} \mathrm{~S}$ on the surface of coal gangue dumps can confirm only the severely self-ignited areas; in these areas, fire point temperatures are initially close to the selfignition temperature on the land surface. Thus, to determine the distribution of internal spontaneous combustion areas and the internal temperatures and gas concentrations of $\mathrm{CO}$ and $\mathrm{H}_{2} \mathrm{~S}$ in these detection boreholes within coal gangue dumps, the boreholes deep into the normal areas of the gangue dumps are drilled with truck drillers. The depth of these detection drillings is decided in accordance with the side conditions. The depth is $2 \mathrm{~m}$ under the surface of coal gangue dumps, and the diameter is $75 \mathrm{~mm}$. The adjacent detection drillings during construction are close to each other after the first thinning. Therefore, the internal spontaneous combustion areas are gradually confirmed.

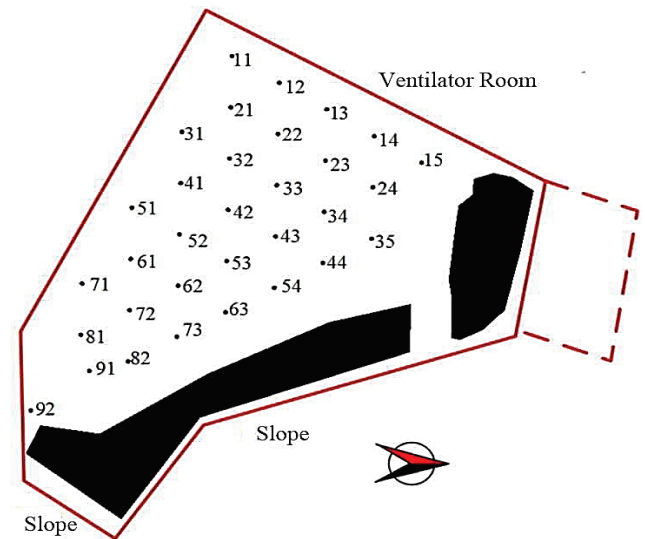

Figure 9 Layout of detection drillings of $2^{\#}$ under coal gangue dump

Table 2 Detected results of temperatures and gas concentrations of CO and $\mathrm{H}_{2} \mathrm{~S}$ in drilling

\begin{tabular}{|c|c|c|c|c|c|c|c|}
\hline $\begin{array}{l}\stackrel{\Xi}{\Xi} \\
\stackrel{0}{0}\end{array}$ & 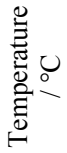 & $\frac{\Xi}{0}$ & 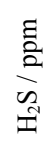 & $\begin{array}{l}\stackrel{\Xi}{0} \\
\stackrel{0}{0}\end{array}$ & 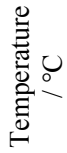 & $\frac{\Xi}{2}$ & 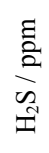 \\
\hline 11 & 446 & 905 & 83 & 43 & 75 & 45 & 5 \\
\hline 12 & 327 & 472 & 156 & 44 & 230 & 840 & 132 \\
\hline 13 & 167 & 80 & 76 & 51 & 90 & 43 & 6 \\
\hline 14 & 85 & 46 & 18 & 52 & 236 & 62 & 79 \\
\hline 15 & 88 & 37 & 10 & 53 & 186 & 430 & 127 \\
\hline 21 & 367 & 874 & 145 & 54 & 551 & 671 & 90 \\
\hline 22 & 249 & 76 & 140 & 61 & 61 & 44 & 6 \\
\hline 23 & 77 & 32 & 9 & 62 & 238 & 77 & 80 \\
\hline 24 & 189 & 568 & 83 & 63 & 167 & 66 & 85 \\
\hline 31 & 84 & 32 & 16 & 71 & 149 & 78 & 119 \\
\hline 32 & 493 & 760 & 136 & 72 & 250 & 326 & 79 \\
\hline 33 & 178 & 86 & 80 & 73 & 83 & 70 & 99 \\
\hline 34 & 74 & 43 & 8 & 81 & 165 & 328 & 104 \\
\hline 35 & 92 & 78 & 22 & 82 & 73 & 49 & 11 \\
\hline 41 & 174 & 88 & 156 & 91 & 510 & 80 & 129 \\
\hline 42 & 542 & 890 & 122 & 92 & 340 & 77 & 120 \\
\hline
\end{tabular}

A case study on the detection of the internal spontaneous combustion areas of $2^{\#}$ under coal gangue dump of Yuquan coal mine is presented. The boreholes deep into the normal surface areas of $2^{\#}$ under coal gangue dump are drilled with truck drillers, and the distance between any two adjacent boreholes is $10 \mathrm{~m}$ (Fig. 9). The multiparameter gas detectors are used to detect the gas concentrations of $\mathrm{CO}$ and $\mathrm{H}_{2} \mathrm{~S}$ within the drillings orifice. The detected temperatures and gas concentrations of $\mathrm{CO}$ and $\mathrm{H}_{2} \mathrm{~S}$ are given in Tab. 2. The detection boreholes are timely sealed by cement once detection is completed. 
Two embedded temperature sensors are installed in two detection drillings sealed with cement. Fig. 10 shows the supplementary detection drillings in the intermediate position between the high-temperature drilling and the non-high-temperature drilling. Tab. 3 lists the detected temperatures and gas concentrations of $\mathrm{CO}$ and $\mathrm{H}_{2} \mathrm{~S}$ within supplementary drillings. The judge accuracy of the internal spontaneous combustion areas is $5 \mathrm{~m}$. Thus, improving the judge accuracy of the internal spontaneous combustion areas is unnecessary. The detected results of temperatures and gas concentrations of $\mathrm{CO}$ and $\mathrm{H}_{2} \mathrm{~S}$ in drillings and supplementary drillings show the internal spontaneous combustion areas (dark areas in Fig. 11) of $2^{\#}$ under coal gangue dump.

Table 3 Detected results of temperatures and gas concentrations of CO and $\mathrm{H}_{2} \mathrm{~S}$ in supplementary drillings

\begin{tabular}{|c|c|c|c|c|c|c|c|}
\hline م. & 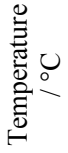 & $\frac{\Xi}{0}$ & $\begin{array}{c}\Xi \\
\stackrel{\Xi}{2} \\
\text { in } \\
\tilde{I}\end{array}$ & $\begin{array}{l}\stackrel{\vec{\Xi}}{0} \\
\stackrel{0}{2}\end{array}$ & 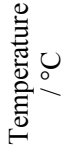 & $\frac{\Xi}{0}$ & $\frac{\Xi}{\tilde{D}}$ \\
\hline $1_{\mathrm{s}}$ & 180 & 96 & 71 & $10_{\mathrm{s}}$ & 561 & 746 & 145 \\
\hline $2_{\mathrm{s}}$ & 81 & 43 & 12 & $11_{\mathrm{s}}$ & 239 & 831 & 129 \\
\hline $3_{\mathrm{s}}$ & 260 & 77 & 126 & $12_{\mathrm{s}}$ & 73 & 30 & 16 \\
\hline $4_{\mathrm{s}}$ & 439 & 779 & 125 & $13_{\mathrm{s}}$ & 433 & 437 & 129 \\
\hline 5 s & 234 & 591 & 79 & $14_{\mathrm{s}}$ & 195 & 78 & 87 \\
\hline $6_{s}$ & 78 & 23 & 18 & $15_{\mathrm{s}}$ & 261 & 891 & 120 \\
\hline $7 \mathrm{~s}$ & 82 & 59 & 77 & $16_{\mathrm{s}}$ & 91 & 48 & 22 \\
\hline $8_{\mathrm{s}}$ & 90 & 55 & 12 & $17_{\mathrm{s}}$ & 342 & 736 & 103 \\
\hline $9_{\mathrm{s}}$ & 327 & 938 & 120 & $18_{\mathrm{s}}$ & 423 & 541 & 121 \\
\hline
\end{tabular}

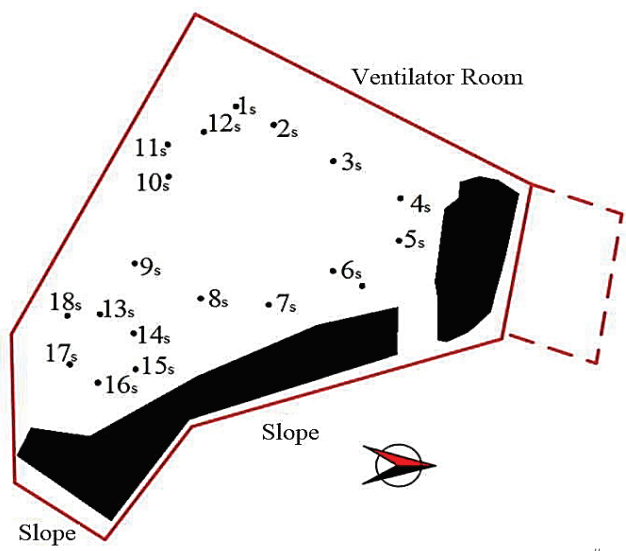

Figure 10 Layout of supplementary detection drillings of $2^{\#}{ }_{\text {under }}$ coal gangue dump (s: supplementary)

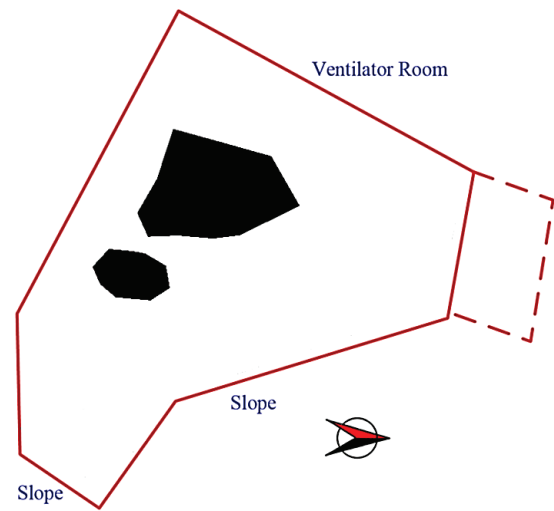

Figure 11 Internal spontaneous combustion areas (dark areas) of $2 \#_{\text {under }}$ coal gangue dump
Therefore, the obtained areas of abnormal surface areas (Fig. 6) and internal spontaneous combustion areas (Fig. 11) of $2^{\#}$ under coal gangue dump show the acquired spontaneous combustion areas of $2^{\#}$ under coal gangue dump (Fig. 12). Using the above method, the spontaneous combustion areas of coal gangue dumps in Yuquan coal mine are determined (Fig. 13).

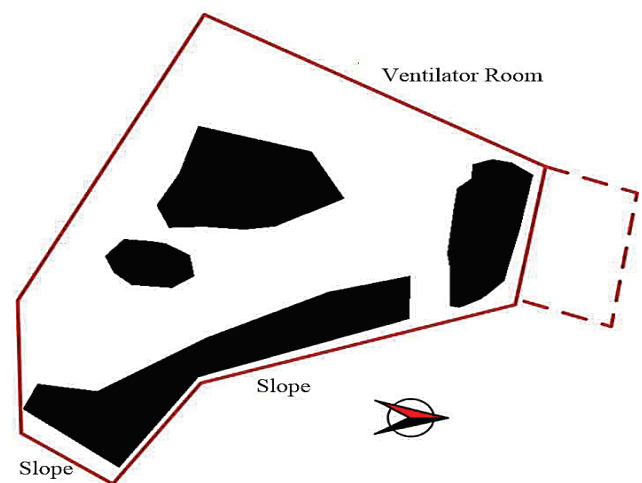

Figure 12 Spontaneous combustion areas (dark areas) of $2^{\#}$ under coal gangue dump

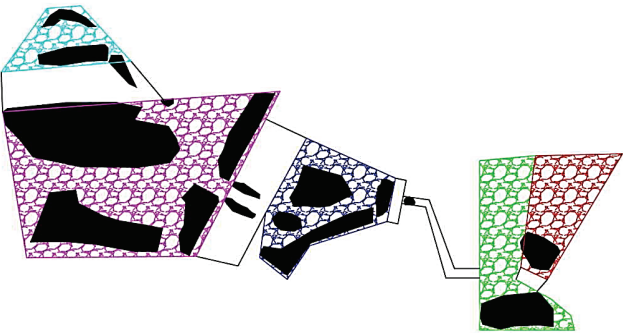

Figure 13 Spontaneous combustion areas (dark areas) of coal gangue dumps in Yuquan coal mine

\subsubsection{LCD injection system}

The liquid storage tank is equipped with safety devices, including the control valve, safety valve, pressure gauge, thermometer, level gauge, explosion-proof cover, backstop, and safe relief device; in this way, the normal operation of the mobile prevention and extinguishing system of spontaneous combustion using LCD can be ensured. The tank parameters are shown in Tab. 4. The reasonable flow controlled by control valves in the liquid storage tank of the injection system and the injection time of each injection hole are $2 \mathrm{t} / \mathrm{h}$ and $1 \mathrm{~min}$, respectively; these results are due to the site conditions of coal gangue dumps. LCD passes successively through the liquid storage tank, liquid phase pipelines, ZGK high-vacuum insulation pipes, and injection equipment.

Table 4 Liquid storage tank parameters

\begin{tabular}{|c|c|c|}
\hline Serial number & Parameter & Value \\
\hline 1 & Working medium & LCD \\
\hline 2 & Purity & $99,9 \%$ \\
\hline 3 & Design pressure & $2,5 \mathrm{MPa}$ \\
\hline 4 & Working pressure & $1,0 \mathrm{MPa}$ to $2,2 \mathrm{MPa}$ \\
\hline 5 & Working temperature & $-30^{\circ} \mathrm{C}$ to $-40^{\circ} \mathrm{C}$ \\
\hline 6 & Rated gas production & $10000 \mathrm{Nm}^{3}$ \\
\hline 7 & Volume & $6,5 \mathrm{~m}^{3}$ \\
\hline 8 & Net weight of tank & $10 \mathrm{t}$ \\
\hline 9 & Texture & carbon steel \\
\hline 10 & Structure & inside tank and outside tank \\
\hline 11 & Performance & $\begin{array}{c}\text { good heat insulation and high } \\
\text { compression properties }\end{array}$ \\
\hline
\end{tabular}


ZGK high-vacuum insulation pipes consist of austenitic stainless steel pipes, Teflon, and metal bellows. These pipes are employed to inject LCD for preventing the gasification of LCD in the injection process and fully using its spontaneous combustion prevention and extinguishing performance. LCD injection holes are drilled with an equilateral triangle layout. The parameters (including diameter, interval, and depth) of the injection can significantly influence the controlling effect and relevant economic factors. Extremely large diameter and depth and considerably small interval of these injection holes can result in costly operation. However, significantly small diameter and depth and exceedingly large interval of these injection holes can reduce the controlling effect. In consideration of the controlling effect and relevant economic factors, the diameter, interval, and depth of these injection holes are determined as $60 \mathrm{~mm}, 4 \mathrm{~m}$, and $5 \mathrm{~m}$, respectively. The length of the perforated pipe installed on the forepart of ZGK highvacuum insulation pipe is $1 \mathrm{~m}$ to ensure the injection effect of LCD length. The structural schematic and layout of LCD injection holes are shown in Figs. 14 and 15, respectively. The boreholes are sealed with cement after completing the LCD injection operation.
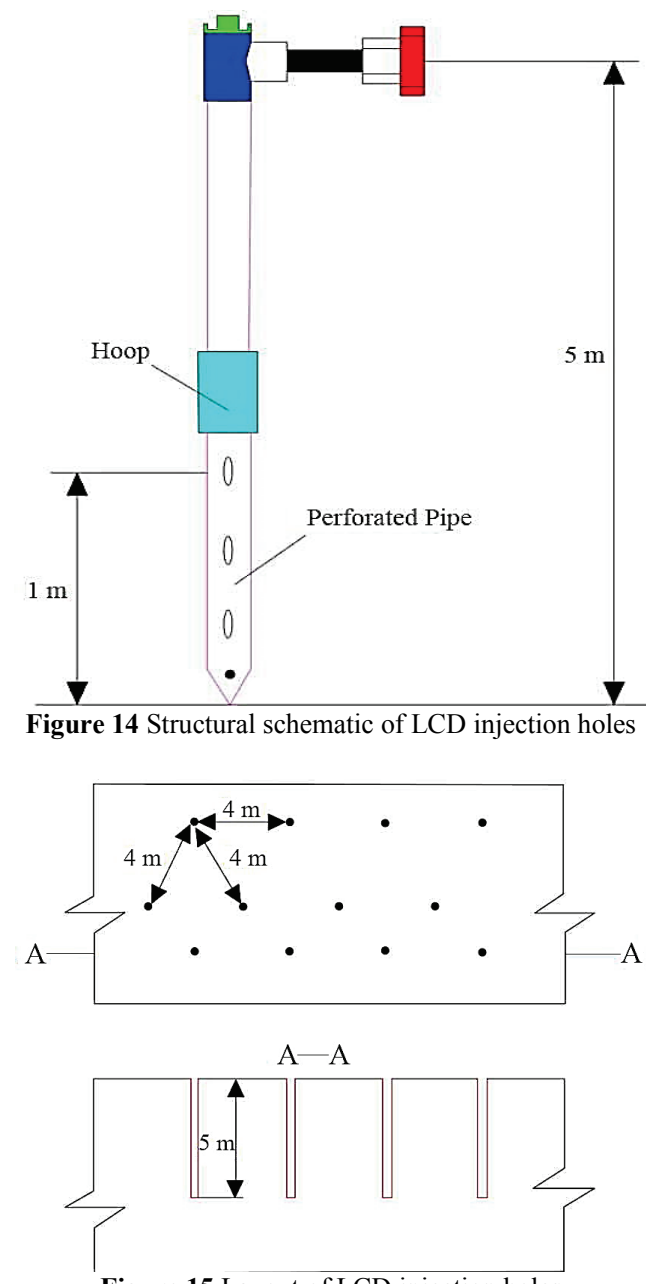

Figure 15 Layout of LCD injection holes

The inlets of the pump and gas-liquid converter of self-heating type are connected to the outlet in the bottom of the liquid storage tank. The outlets of the pump and gas-liquid converter of self-heating type are connected with the inlet on the top of the liquid storage tank. The carbon dioxide can present as liquid only when its temperature is between $-56,6$ and $31,1^{\circ} \mathrm{C}$, and pressure is between 0,417 and $7,09 \mathrm{MPa}$. The temperatures of the gas-liquid converter and the liquid storage tank are maintained in the range of $-56,6^{\circ} \mathrm{C}$ to $31,1{ }^{\circ} \mathrm{C}$. Therefore, the phase state of carbon dioxide depends only on its applied pressure. The self-pressurization control system is designed and constructed to maintain the pressure in the liquid storage tank at $1,0 \div 2,2 \mathrm{MPa}$. The solidification of LCD is avoided owing to the pressure decrease in the liquid storage tank with the constant decrease in LCD level in the liquid tank, booster pump, gas-liquid converter, liquid phase pipelines, and highvacuum insulation pipes. The complete release of LCD in the liquid storage tank is ensured. The reasonable flow controlled by control valves of the self-pressurization system is $0,5 \mathrm{t} / \mathrm{h}$. The flows of the booster pump and the gas-liquid converter are all $0,25 \mathrm{t} / \mathrm{h}$.

Half of LCD from the liquid storage tank passes successively through liquid phase pipelines, booster pump, liquid-gas mixed phase pipelines, and liquid storage tank; as a result, the pressure in the liquid storage tank is enhanced and the complete release of LCD is ensured. The other half of LCD from the liquid storage tank passes successively through liquid phase pipelines, gas-liquid converter, liquid-gas mixed phase pipelines, gas phase pipelines, and liquid phase pipelines; consequently, the pressure in the booster pump, gas-liquid converter, liquid phase pipelines, and high-vacuum insulation pipes is enhanced. The heat from surrounding environment gasifies LCD in the gas-liquid converter. Tab. 5 provides the parameters of the gas-liquid converter of self-heating type.

Table 5 Parameters of the gas-liquid converter of self-heating type

\begin{tabular}{|c|l|c|}
\hline $\begin{array}{c}\text { Serial } \\
\text { number }\end{array}$ & \multicolumn{1}{|c|}{ Parameters } & Values \\
\hline 1 & Type & YQH-3000 \\
\hline 2 & Gasification Capability & $1500 \mathrm{Nm}^{3} / \mathrm{h}$ \\
\hline 3 & Consumption of LCD & $3 \mathrm{t} / \mathrm{h}$ \\
\hline 4 & Maximum working pressure & $2,5 \mathrm{MPa}$ \\
\hline 5 & $\begin{array}{l}\text { Designed maximum working } \\
\text { pressure }\end{array}$ & $2,6 \mathrm{MPa}$ \\
\hline 6 & Test pressure & $2,87 \mathrm{MPa}$ \\
\hline 7 & Ultimate pressure & $3,0 \mathrm{MPa}$ \\
\hline
\end{tabular}

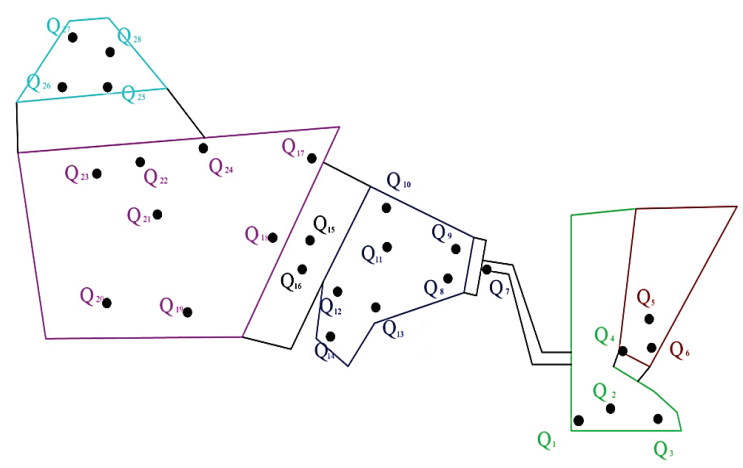

Figure 16 Layout of points for testing index gases concentration

\subsubsection{Index gas concentration measurement}

The testing points for measuring the concentration of index gases are arranged in the spontaneous combustion 
areas of coal gangue dumps based on the early detection results in the detection system of spontaneous combustion areas and the site conditions of coal gangue dumps. Fig. 16 shows the layout of these testing points, which are labeled as $\mathrm{Q}_{1}, \mathrm{Q}_{2}, \ldots, \mathrm{Q}_{27}$, and $\mathrm{Q}_{28}$.

The relationships of the average concentrations of $\mathrm{CO}$ and $\mathrm{H}_{2} \mathrm{~S}$ to time for all the coal gangue dumps of Yuquan coal mine are shown in Figs. 17 and 18.

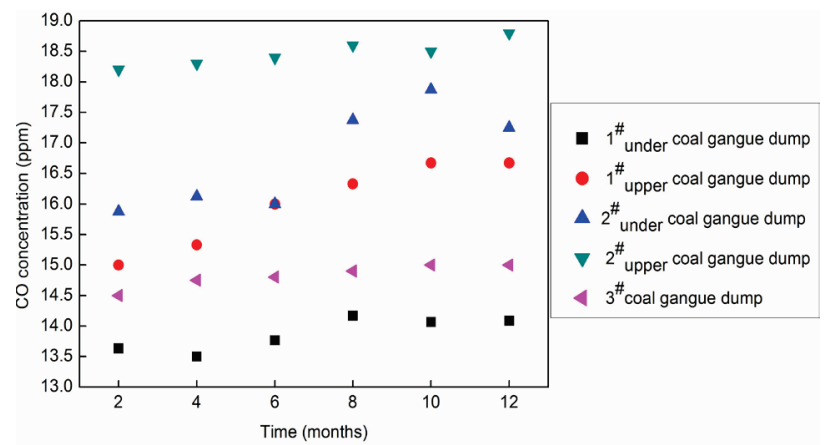

Figure 17 Relationship of CO average concentration to time

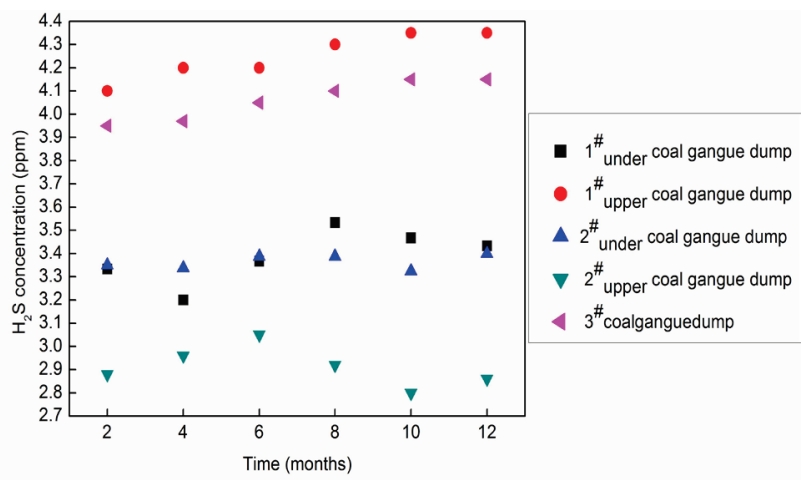

Figure 18 Relationship of $\mathrm{H}_{2} \mathrm{~S}$ average concentration to time

\subsubsection{Internal temperature measurement}

The detection system of spontaneous combustion areas detects 21 drillings sealed by cement right after completing the installation of the temperature sensors. These drillings are used to test the control effect of spontaneous combustion. The layout of these drillings (labeled as $\mathrm{L}_{1}, \mathrm{~L}_{2}, \ldots, \mathrm{L}_{20}, \mathrm{~L}_{21}$ ) as the testing points for measuring the internal temperature in coal gangue dumps is shown in Fig. 19. The relationship of the average internal temperature in the coal gangue dumps to time is shown in Fig. 20.

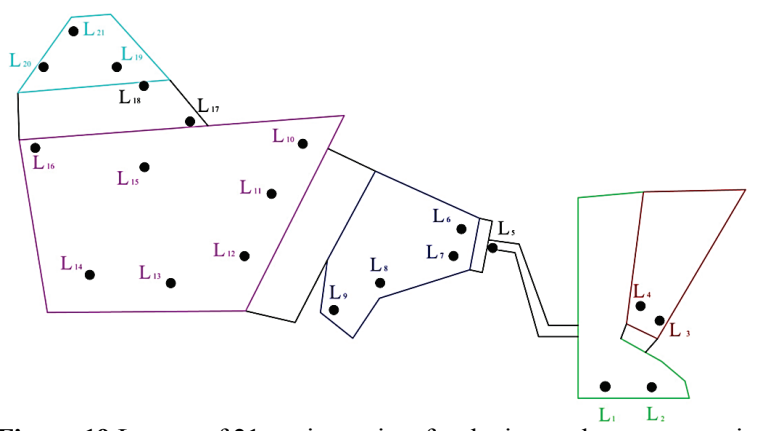

Figure 19 Layout of 21 testing points for the internal temperature in coal gangue dumps

The monitored results clearly show that, after applying the detection system of spontaneous combustion areas and the mobile prevention and extinguishing system of spontaneous combustion using LCD, the concentrations of index gases $\mathrm{CO}$ and $\mathrm{H}_{2} \mathrm{~S}$ in the coal gangue dumps of Yuquan coal mine are below 24 and 6,6 ppm, and the internal temperature is below $70{ }^{\circ} \mathrm{C}$. These values are less than the maximum allowable limits specified in "Coal Mine Safety Regulations" in China. Thus, the detection system of spontaneous combustion areas and the mobile prevention and extinguishing system spontaneous combustion using LCD of coal gangue dumps at Yuquan coal mine play a significant role in accurately detecting spontaneous combustion areas and timely taking corresponding control measure.

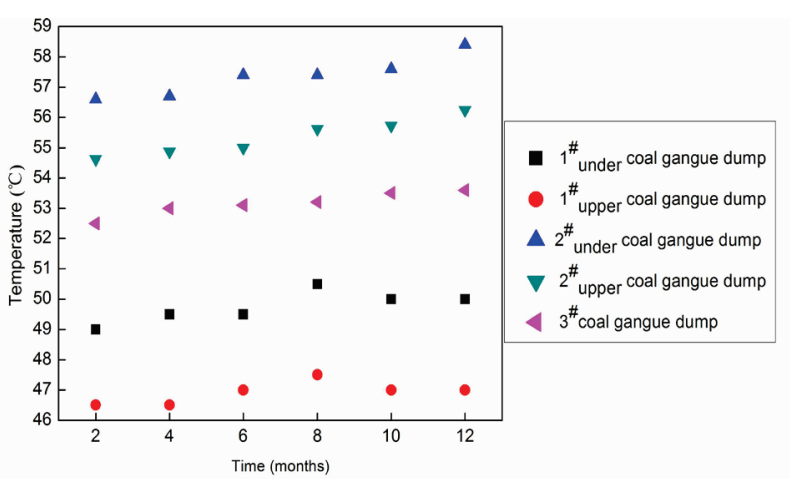

Figure 20 Relationship of average internal temperature of coal gangue dumps to time

The concentrations of $\mathrm{CO}$ and $\mathrm{H}_{2} \mathrm{~S}$ and the internal temperature in the coal gangue dumps must be monitored and analyzed every month to observe possible reignitions. Once recurrence is detected, LCD injection must be implemented into the reignition zones to extinguish fires and cool heat.

\subsubsection{Method for the prevention of the spontaneous combustion in new coal gangues}

The annual discharge quantity of coal gangues in Yuquan coal mine is $1,2 \times 10^{5} \mathrm{t}$. Therefore, preventing the spontaneous combustion in new coal gangues is highly significant.

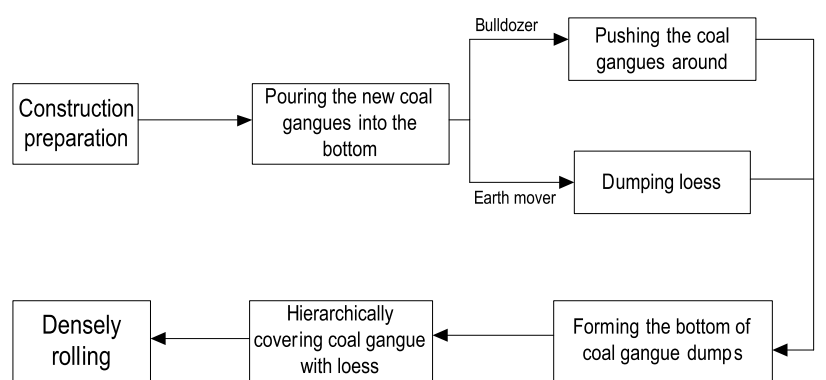

Figure 21 Flowchart of the method of hierarchically rolling and coverage using loess

Effectively blocking the channel of air passing into the coal gangue dumps can halt the chain reactions of combustion and force oxidation reaction to stop. Thus, considering the budget and development plans of Yuquan coal mine, the method of hierarchically rolling and covering with loess is adopted to prevent the spontaneous combustion in new coal gangues. Unlike natural dumping and accumulation, the adopted method maintains the 
conveyor face at a certain height and covers the surface of coal gangue hierarchically with loess. The construction machineries of the method mainly include two T120A bulldozers, one W1AC winch, and one YZTI6K earth mover. Fig. 21 shows the flowchart of the method. The detailed specific construction procedure of the method includes 1) building a loess dam of $25 \times 25 \times 0,03 \mathrm{~m}$ using a bulldozer and 2) hierarchically pouring $0,2 \mathrm{~m}$-thick loess to cover the coal gangue dumps, with a slope of $30^{\circ}$ and a stack height of $8 \mathrm{~m}$.

Table 6 Cost summary of the control system of spontaneous combustion in Yuquan coal mine

\begin{tabular}{|c|c|c|c|c|c|c|}
\hline $\begin{array}{l}\text { Serial } \\
\text { Number }\end{array}$ & Item of cost & Specific items & $\begin{array}{l}\text { Usage } \\
\text { amount }\end{array}$ & Unit cost $/ \$$ & Cost $/ \$$ & $\begin{array}{l}\text { Accounting for the } \\
\text { proportion of the } \\
\text { total cost } / \%\end{array}$ \\
\hline \multirow{5}{*}{1} & \multirow{5}{*}{$\begin{array}{c}\text { Detection system of } \\
\text { spontaneous } \\
\text { combustion areas }\end{array}$} & $\begin{array}{c}\text { Portable infrared radiation } \\
\text { thermometer }\end{array}$ & 1 set & 346 & 346 & \multirow{5}{*}{1,9} \\
\hline & & Multi-parameter gas detector & $1 \mathrm{set}$ & 456 & 456 & \\
\hline & & Truck driller & $1 \mathrm{set}$ & 1826 & 1826 & \\
\hline & & $\begin{array}{l}\text { Armored platinum resistance } \\
\text { temperature sensor }\end{array}$ & 2 sets & 31 & 62 & \\
\hline & & PC and Surfer software & 1 set & 708 & 708 & \\
\hline \multirow{10}{*}{2} & \multirow{10}{*}{$\begin{array}{l}\text { Mobile spontaneous } \\
\text { combustion prevention } \\
\text { and extinguishing } \\
\text { system }\end{array}$} & Liquid storage tank & $1 \mathrm{set}$ & 110180 & 110180 & \multirow{10}{*}{92,9} \\
\hline & & $\begin{array}{l}\text { Gas-liquid converter of } \\
\text { self-heating type }\end{array}$ & 1 set & 15740 & 15740 & \\
\hline & & Booster pump & 1 set & 14166 & 14166 & \\
\hline & & Injection equipment & 1 set & 7870 & 7870 & \\
\hline & & Control valve & 9 sets & 1574 & 14166 & \\
\hline & & High vacuum insulation pipe & $1 \mathrm{~m}$ & 803 & 803 & \\
\hline & & Liquid phase pipe & $7 \mathrm{~m}$ & 47 & 329 & \\
\hline & & Gas phase pipe & $5 \mathrm{~m}$ & 63 & 315 & \\
\hline & & Liquid-gas mixed phase pipe & $4 \mathrm{~m}$ & 31 & 124 & \\
\hline & & Truck driller & $1 \mathrm{set}$ & 1826 & 1826 & \\
\hline \multirow[b]{2}{*}{3} & \multirow{2}{*}{$\begin{array}{c}\text { Spontaneous } \\
\text { combustion effect- } \\
\text { testing system }\end{array}$} & Multi-parameter gas detector & 1 set & 456 & 456 & \multirow[b]{2}{*}{0,3} \\
\hline & & $\begin{array}{l}\text { Armored platinum resistance } \\
\text { temperature sensor }\end{array}$ & 21 sets & 3 & 63 & \\
\hline \multirow{2}{*}{4} & \multirow{2}{*}{ Raw material } & Liquid carbon dioxide & $6,7 \mathrm{t}$ & 157 & 1051,9 & \multirow{2}{*}{0,9} \\
\hline & & Cement & $12 \mathrm{t}$ & 47 & 564 & \\
\hline 5 & Labor & Worker & 5 workers & 1417 & 7085 & 4 \\
\hline \multicolumn{5}{|c|}{ Total } & 178136,9 & 100 \\
\hline
\end{tabular}

\subsection{Cost of the control system of spontaneous combustion}

Table 6 summarizes the cost of the control system of spontaneous combustion in Yuquan coal mine. Among the total cost $(\$ 178136,9)$, the costs of detection system of spontaneous combustion areas, mobile prevention and extinguishing system of spontaneous combustion, effecttesting system of spontaneous combustion, raw material, and labor account for $1,9 \%, 92,9 \%, 0,3 \%, 0,9 \%$ and $4 \%$, respectively. The overall cost of equipment accounts for $95,1 \%$, which is significantly higher than that of raw materials and labor $(4,9 \%)$. The total area of coal gangue dumps in Yuquan coal mine is $22300 \mathrm{~m}^{2}$. Therefore, the cost per square meter of the control system of spontaneous combustion is approximately $\$ 8$. Compared with the cost of potential risks, including economic loss, environmental pollution, and casualties, caused by the coal gangue dumps, this value indicates that the proposed control system is economical.

\section{Conclusion}

In this study, a control system of spontaneous combustion in coal gangue dumps was designed and constructed on the basis of the studies on the process of spontaneous combustion and the site conditions in Yuquan coal mine. The proposed control system was used to effectively and specifically control the effect of spontaneous combustion in coal gangue dumps. The obtained conclusions are as follows.

(1) The detection system can accurately position the surface and internal spontaneous combustion zones of coal gangue dumps by measuring the temperature and the concentration of index gases of coal gangue dumps using its infrared radiation thermometers, gas detector, temperature sensor, and the data-based isothermal figures plotted with the Surfer software.

(2) The control system with its high cryogenic LCD expansion, infiltration, and adsorption capacities can timely inject LCD into the internal spontaneous combustion zones to widely refrigerate, cool, suffocate, and extinguish coal gangue dumps fires and warm areas in coal gangue dumps.

(3) The concentrations of index gases $\mathrm{CO}$ and $\mathrm{H}_{2} \mathrm{~S}$ and the internal temperature in coal gangue dumps of Yuquan coal mine are verified by the effect-checking system. Their values are below $24 \mathrm{ppm}, 6,6 \mathrm{ppm}$, and $70{ }^{\circ} \mathrm{C}$. These values are less than the maximum allowable limits specified in "Coal Mine Safety Regulations" in China. The cost per square meter of the control system of spontaneous combustion is approximately $\$ 8$. Therefore, the proposed control system is economical and effective.

(4) The method of hierarchically rolling and covering with loess was adopted to prevent the spontaneous combustion in new coal gangues in consideration of the budget and development plans of Yuquan coal mine. 
This study can satisfy the demands of mine operators in accurately detecting spontaneous combustion zones in coal gangue dumps and taking effective measures to control spontaneous combustion in the Yuquan coal mine. However, the control system of spontaneous combustion in coal gangue dumps is limited by special conditions in the Yuquan coal mine. Further study is needed to solve the applicability of the proposed control system in coal gangue dumps under special conditions.

\section{Acknowledgment}

The authors are thankful to the Yuquan coal mine for their permission to publish this paper. The authors also acknowledge the support from the Program for the Outstanding Young Scientists of Shandong University of Science and Technology (Project No. 2015JQJH105), and the Taishan Scholar Talent Team Support Plan for Advantaged and Unique Discipline Areas.

\section{References}

[1] Zhou, C. C.; Liu, G. J.; Wu, D.; Fang, T.; Wang, R. W.; Fan, X. Mobility behavior and environmental implications of trace elements associated with coal gangue: a case study at the huainan coalfield in China. // Chemosphere. 95, 1(2014), pp. 193-199.

[2] Dewi, K.; Khair, H.; Irsyad, M. Development of green pavement for reducing oxides of nitrogen (NOx) in the ambient air. // Journal of Engineering and Technological Sciences. 48, 2(2016), pp. 159-172. DOl: 10.5614/j.eng.technol.sci.2016.48.2.3

[3] Wang, S. B.; Luo, K. L.; Wang, X.; Sun, Y. Z. Estimate of sulfur, arsenic, mercury, fluorine emissions due to spontaneous combustion of coal gangue: An important part of Chinese emission inventories. // Environmental Pollution. 209, (2016), pp. 107-113. DOI: 10.1016/j.envpol.2015.11.026

[4] Querol, X.; Zhuang, X.; Font, O.; Izquierdo, M.; Alastuey, A.; Castro, I.; Van Drooge, B. L.; Moreno, T.; Grimalt, J. O.; Elviva, J.; Cabanas, M.; Bartroli, R.; Hower, J. C.; Ayora, C.; Plana, F.; Lopez-Soler, A. Influence of soil cover on reducing the environmental impact of spontaneous coal combustion in coal waste gobs: a review and new experimental data. // International Journal of Coal Geology. 85, 1(2011), pp. 2-22. DOI: doi.org/10.1016/j.coal.2010.09.002

[5] Zhou, C. C.; Liu, G. J.; Wu, S. C.; Lam, P. K. S. The environmental characteristics of usage of coal gangue in bricking-making: a case study at Huainan, China. // Chemosphere. 95, (2014), pp. 274-280. DOl: 10.1016/j.chemosphere.2013.09.004

[6] Zhou, C. C.; Liu, G. J.; Yan, Z. C.; Fang, T.; Wang, R. W. Transformation behavior of mineral composition and trace elements during coal gangue combustion. // Fuel. 97, (2012), pp. 644-650. DOI: 10.1016/j.fuel.2012.02.027

[7] Shao, H.; Zhou, F. B.;Chen, K. Y.; Cheng, J. W.; Melogh, P. H. Study on the hydrogen generation rules of coal oxidation at low temperature. // Journal of Engineering Science and Technology Review. 7, 3(2014), pp. 90-95.

[8] Fu, T. L.; Wu, Y. G.; Ou, L. S.; Yang, G.; Liang, T. C. Effects of thin covers on the release of coal gangue contaminants. // Energy Procedia. 16, (2012), pp. 327-333. DOI: 10.1016/j.egypro.2012.01.054

[9] Mao, Z. L.; Zhu, H. Y.; Zhao, X. J.; Sun, J. H.; Wang, Q. S. Experimental study on characteristic parameters of coal spontaneous combustion. // Procedia Engineering. 62, (2013), pp. 1081-1086. DOI: 10.1016/j.proeng.2013.08.164

[10] Zhou, N.; Han, X. L.; Zhang, J. X.; Li, M. Compressive deformation and energy dissipation of crushed coal gangue.
// Powder Technology. 297, (2016), pp. 220-228. DOI: 10.1016/j.powtec.2016.04.026

[11] Zhang, H. F.; Gao, E. X.; Zhang, X. C. Comprehensive study on bituminous coal oxidation by TGA-DTA-FTIR experiment. // Journal of Power Technologies. 95, 3(2015), pp. 167-174.

[12] Xu, W. B.; Song, W. D.; Wang, D. X.; Pan, W. D. Energy dissipation properties of cement backfill body under triaxial compression conditions. // Journal of China University of Mining \& Technology. 43, 5(2014), pp. 808-814.

[13] Zhang, J. X.; Huang, Y. L.; Li, M.; Zhang, Q.; Liu, Z. Test on mechanical properties of solid backfill materials. // Materials Research Innovations, 18(sup2), (2014), pp. S2960.

[14] Chen, J.; Liu, G. J.; Kang, Y.; Wu, B.; Sun, R. Y.; Zhou, C. C.; Wu, D. Atmospheric emissions of F, As, Se, Hg, and Sb from coal-fired power and heat generation in China. // Chemosphere. 90, 6(2013), pp. 1925-1932. DOI: 10.1016/j.chemosphere.2012.10.032

[15] Kim, A G.; Chaiken, R. F. Fires in abandoned coal mines and waste banks. US Department of the Interior, Bureau of Mines, 1993.

[16] Rynk, R. Fires at composting facilities: handling and extinguishing fires. // Part II. BioCycle. 41, 2(2004), pp. 5862.

[17] Dalverny, L. E.; Chaiken, R. F. Mine fire diagnostics and implementation of water injection with fume exhaustion at Renton, PA. US Department of the Interior, Bureau of Mines, 1991.

[18] Jones, J. R.; Kim, A. G.; Kociban, A. M. The use of containment barriers and fire fighting foams for the extinguishment of coal waste bank fires: a laboratory study. // Carbon. 19, (1994), pp. 64-42. DOI: 10.21000/jasmr94040121

[19] Kim, A. G.; Kociban, A. M. Cryogenic slurry method to extinguish waste bank fires. // In Proceedings of the International Land Reclamation and Mine Drainage Conference and the Third International Conference on the Abatement of Acidic Drainage. 4, (1994), pp. 129-138. DOI: 10.21000/jasmr94040129

\section{Authors' addresses}

Gang Wang, Ph.D., Associate Professor

Laboratory of Mine Disaster Prevention and Control, College of Mining and Safety Engineering,

Shandong University of Science \& Technology, Room 108, 579 Qianwangang Road Economic \& Technical Development Zone, Qingdao Shandong Province, 266590 P. R. China E-mail: Gang.Wang@sdust.edu.cn

\section{Qiqi Liu, Postgraduate} Guoqiang Yan, Postgraduate

Lulu Sun, Ph.D. (Corresponding author)

Shandong University of Science \& Technology, 579 Qianwangang Road Economic \& Technical Development Zone, Qingdao Shandong Province, 266590 P. R. China E-mail: 15764227280@163.com

E-mail: 4513645ygq@163.com

E-mail: sunlukdck@sina.com

\section{Hongyuan Qu, Ph.D.}

Colorado School of Mines,

1500 Illinois St Golden, Colorado 80402, United States.

E-mail: HongyuanQu@hotmail.com

Qingfang Han, Ph.D.

Shandong University of Science \& Technology,

579 Qianwangang Road Economic \& Technical Development

Zone, Qingdao Shandong Province, 266590 P. R. China

E-mail: 568191467@qq.com 